\title{
Role of Integrated Sciences Teaching Materials on Pressure Topic to Improve Student's Critical Thinking Skills in Junior
}

\author{
Rahmania $^{1,2}$, Any Fitriani ${ }^{1, *}$, Ida Kaniawati ${ }^{1}$ \\ ${ }^{1}$ Science Education, School of Postgraduate Studies, Indonesia University of Education \\ Setiabudhi 229, Bandung 40154, West Java, Indonesia \\ ${ }^{2}$ SMPN 34 Tebo \\ Serayu Wanareja, Kec. Rimbo Ulu Kab. Tebo, Jambi, Indonesia \\ ${ }^{1}$ Science Education, School of Postgraduate Studies, Indonesia University of Education \\ Setiabudhi 229, Bandung 40154, West Java, Indonesia \\ ${ }^{1}$ Science Education, School of Postgraduate Studies, Indonesia University of Education \\ Setiabudhi 229, Bandung 40154, West Java, Indonesia \\ *Corresponding author's email: anyfitriani [AT] upi.edu
}

\begin{abstract}
This study was aimed to identify student's critical thinking skills through the use of integrated sciences teaching materials on pressure topic. This study was conducted at one of SMP in Cimahi, West Java, Indonesia for the 2015/2016 academic year. It used experimental method with nonequivalent pretest-posttest control group design. There were two classes involved, the experiment class where the students using the integrated sciences teaching materials, while the control class using conventional teaching materials provided at school. Data was respectively collected and analyzed by using student's critical thinking skills test and data analysis tools SPSS version 21. The result shows that there is a significant difference in student's critical thinking in student taught using integrated sciences teaching materials those taught with conventional teaching materials. It can be concluded that there is improvement in critical thinking skills of students in the experiment class compared to the control class. In addition, this study provided of positive impacts on student's active learning and independent learning.
\end{abstract}

Keywords—integrated sciences, teaching materials, crtitical thinking skills

\section{INTRODUCTION}

Learning is a part of the educational system. Learning has various components that act and interact with other components in achieving the learning objectives set. According to [1], in the learning process, there are three major components involved in it, namely teachers, students and teaching materials. In the process occurs transformation of science (teaching materials) of a teacher to the students and the results of the transformation of students gain learning experience. One of the components that are important in the learning system is the existence of teaching materials for students in the learning process, learning materials serves as the initial capital will be used or processed to achieve results. Instructional materials have a very important position in the learning process, one of them as a representative of the teacher's explanation to the students. Through the teaching materials used in learning, students can understand the material and concepts are learned more easily. Teaching materials to help the implementation of the learning process properly and smoothly.

Learning science at the junior high school level should already be using the integrated pattern. Even the curriculum in 2013, has required learning science and social studies to be integrated starting from 2014. Integrated learning is learning that allows students either individually or in groups actively searching, digging, and found the concepts and principles of holistic (comprehensive) and authentic. Learning that allows active students will create learning more meaningful. Integrated learning has characteristics according to the Kemdikbud [2] that is holistic, meaningful, authentic and active. Fogarty [3] argued that the integration here means it can meaningfully connect the similar topics under the same subject, with an assumption that students are not able to connect automatically from the material that has been learned before with the other materials. 
In fact, the teaching materials used by teachers are still in the form of study materials fragmentary no relation to one another. Teachers still use learning resources that are available in the form of textbooks from different publishers there. In addition, teachers also still have limited ability to develop teaching materials in an integrated manner. Science teacher who has a different educational backgrounds are still experiencing difficulties in making science teaching materials in an integrated and potentially biased in developing an integrated science teaching materials.

From the results of the evaluation undertaken in the education of students in Indonesia. Students were still accustomed to using standard thinking. Students unfamiliar with complex thinking, that means there are still many students who are weak in critical thinking skills. This has an impact on the evaluation carried out in both the international and national level. Indonesia quality on an international scale is in order under which the test PISA, TIMSS and PIRLS. As well as on a national scale IPA ability junior high school students is still low. The thought process standard Indonesian students still need to be developed into critical thinking skills as one of the complex thought process. Critical thinking skills of students can be developed one through integrated science teaching materials developed by teachers. Students are stimulated to think in complex integration of multiple disciplines of Physics, Chemistry and Biology are relevant to the conditions of everyday life. The integration provides opportunities for students to make sense of the relationships between concepts clump of IPA thus helping students in solve problem. In line with the opinion of [4] that the development of thinking skills to the fullest done through meaningful learning, because it is basically the ability to think someone is always evolving and can be studied. In the integrated science teaching materials are overlapping among subjects. According Ballstaedt [5] demands the ability to cross each other in an integrated learning across disciplines leads students to think complex and increase the students' reasoning ability. According to research results of [6] and [7] that the use of integrated science teaching materials can enhance the student's high-level thinking skills, because students are using more integrated science teaching materials guided and encouraged to develop the capacity to think comprehensively. Critical thinking skills are part of the higher-level thinking. Based on research [8] that integrated science teaching materials can improve student's critical thinking skills because students are more active and independent in learning. According Sukarno [9] that one of the hallmarks of science teaching materials developed by the teacher gives a great chance one of them to increase students' critical thinking skills.

Pressure topic in 8th Junior can be used in the preparation of integrated science teaching materials, since there are two subjects Physics and Biology. In the subjects of Physics, this topic discusses the pressure, hydrostatic pressure, capillarity, pressure liquid in a closed space, the buoyant force and air pressure. In the subjects of biology, this topic discusses human transportation systems, transportation systems in plants, and the respiratory system in humans. On the topic of this pressure there is an overlapping between physics and biology, so it can lead students to interpret between the concepts as a whole and stimulate critical thinking skills.

Based on the description above, it is necessary to improve students' critical thinking skills in science especially about pressure. The purpose of this study is to determine the role of integrated science teaching materials pressure topics on students' critical thinking skills.

\section{METHODS}

The methods is a quasi experiment methods [10]. Nonequivalent pretest-posstest control group design was the design of this research [11]. In this design the students' critical thinking skills measured with pretest and posttest.

In this research, after the pretest and post-test each is treated, where the experiment use of integrated science teaching materials and conventional teaching materials provided at school for the control group. The experimental class using the integrated science teaching materials with their overlapping between physics and biology on the topic of pressure, while the control class using conventional science teaching materials was separated between physics and biology materials. Population and sample in this research are all 8th grade of one of junior high school in Cimahi. Sample of this research are two classes from the population. Purposive sampling was used as the sampling technique.

Initial ability test as prerequisite for sample selection between the experimental group and the control group was performed by using t-test. The test of the students' critical thinking skills was constructed as a research instrument to collect the basics of student's critical thinking skills, including the elementary clarification, basic support, advanced clarification and strategies and tactics. Data analysis was performed by using non parametric statistics ( Mann-Whitney test) which processed by the normality and homogeneity test that were analyzed by using the Shapiro-Wilk test and Levene's test, respectively with help data analysis software IBM SPSS version 21.

\section{RESULTS AND DISCUSSION}

The improvement of student's critical thinking skills who had use of integrated sciences teaching materials and use of conventional teaching material can be seen in Table 1 . Table 1 shows that the average score on the pretest control class is 
44.93 and the experimental class at 46.39, while the average score on the posttest control class is 53.40 and the experimental class at 64.38 . The average of normalized gain ( $\mathrm{N}$-gain) in the control class is 0.15 and the experimental class is 0.33 . The average normalized gain control class including low category and experimental class is medium category. Based on data from the normalized gain can be concluded that the experimental class students have an increased critical thinking skills higher than the control class.

TABLE 1. Description of student's critical thinking skills improvement of both groups

\begin{tabular}{c|l|r|r|r|r}
\hline \multirow{2}{*}{ Class } & \multirow{2}{*}{ Statistic } & \multicolumn{2}{|c|}{ Score } & \multirow{2}{*}{ N-gain } & Categorize \\
\cline { 3 - 4 } Control & $\mathrm{N}$ & Pretest & Posttest & & \\
\cline { 2 - 4 } & Average & 36 & 36 & 0,15 & Low \\
\cline { 2 - 4 } Experiment & $\mathrm{N}$ & 44,93 & 53,40 & & \\
& Average & 36 & 36 & \multirow{2}{*}{0,33} & Medium \\
& & 46,39 & 64,38 & & \\
\hline
\end{tabular}

TABLE 2. Description of student's critical thinking skills improvement in each level

\begin{tabular}{l|r|r|r|r|r|r}
\hline \multirow{2}{*}{$\begin{array}{l}\text { Critical Thinking } \\
\text { Skills Indicator }\end{array}$} & \multicolumn{4}{|c|}{ Average score } & \multicolumn{3}{c}{ N- Gain } \\
\cline { 2 - 7 } & \multicolumn{2}{|c|}{ Control } & \multicolumn{2}{c}{ Experiment } & \multicolumn{2}{c}{} \\
\hline & Pretest & Posttest & Pretest & Posttest & Control & Experiment \\
\hline $\begin{array}{l}\text { Elementary } \\
\text { clarification }\end{array}$ & 34,17 & 43,33 & 35,28 & 54,72 & 0,08 & 0,31 \\
Basic Support & 46,39 & 58,89 & 53,33 & 73,06 & 0,17 & 0,37 \\
$\begin{array}{l}\text { Advanced } \\
\text { Clarification }\end{array}$ & 45,28 & 56,94 & 53,33 & 68,89 & 0,20 & 0,32 \\
$\begin{array}{l}\text { Strategies and } \\
\text { Tactics }\end{array}$ & 52,78 & 55,83 & 43,61 & 61,67 & 0,05 & 0,31 \\
\hline
\end{tabular}

Table 2 shows the different improvement in each indicator of student's critical thinking skills between the experimental group and the control group. Based on Table 1, there seems descriptively different in which use of integration science teaching materials better in developing student's critical thinking skills rather than use conventional teaching materials. In more detail, student's critical thinking skills in this study were classified into four indicator, description of the improvement for each indicator shows that use of integration science teaching materials better in improving every indicator with use of integration science teaching materials rather than use conventional teaching materials. Comparison of the improvement in each student's critical thinking indicator of both groups can be seen in Fig. 1.

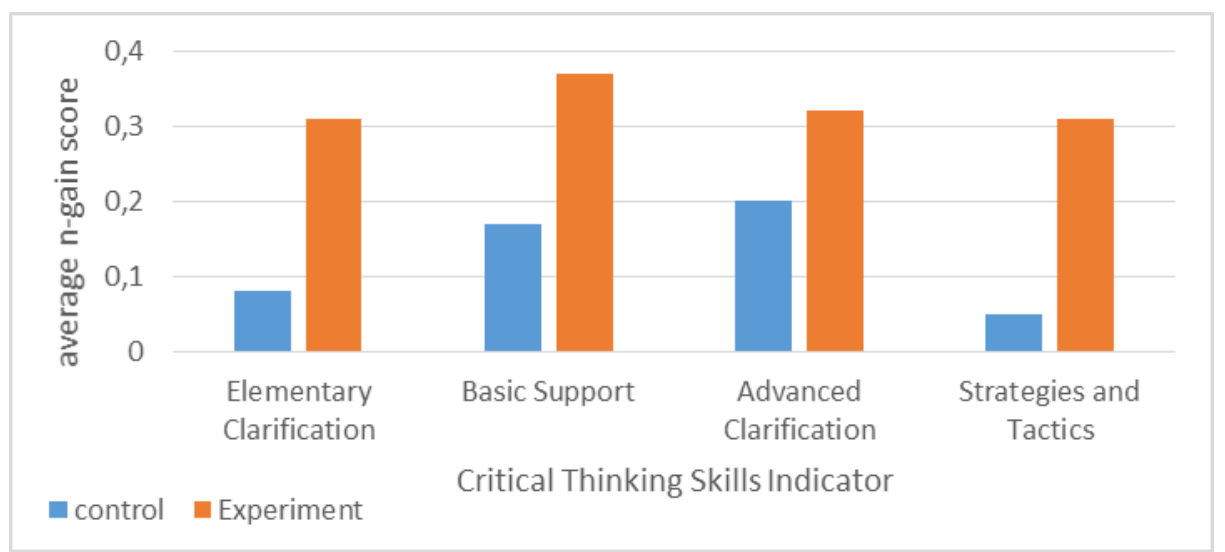

FIGURE 1: Diagram of the average of n-gain score in each indicator of the student's critical thinking skills of both groups. 
Based on the average of the normalized gain for each indicator of the student's critical thinking skills, there is a significant difference between the experimental group and the control group in which the experimental group is superior than the control group in elementary clarification, basic support, advanced clarification, strategies and tactics, this shows that integrated science teaching materials have a different influence with the conventional teaching materials. Integrated science teaching materials can integrate between materials in the one subject and connect between concepts so that it can stimulate the student's critical thinking skills. Comparison of the improvement in each indicator of the student's critical thinking skills both groups represented by n-gain score can be seen in Fig. 1

\section{CONCLUSION}

Based on the analysis, the experimental group increased significantly than the control group. Both groups also showed an improvement that significant different in elementary clarification, basic support, advanced clarification, strategies and tactics at critical thinking skills indicator. In Integrated science teaching materials help students develop critical thinking skills through learning activities presented in the components of teaching materials. Students are more active in learning and teachers more visible role as a facilitator to guide students in learning, so that integrated science teaching materials to help students in the process of critical thinking in the links between the concepts of disciplines into an integrated concept. It implies that the use of integrated science teaching materials can significantly improve student's critical thinking skills on pressure topic than a conventional teaching materials

\section{ACKNOWLEDGMENTS}

We greatly thank to the Faculty members, the lecturer in Science Education Department, School of Postgraduate Studies, Indonesian University of Education and all parties who have given many contribution in this study.

\section{REFERENCES}

[1] Anwar, S. Material Teaching : Management of material teaching. Universitas Pendidikan Indonesia, Bandung, 2014.

[2] Ministry of Education and Cultural. Technical project of integrated thematic learning with scientific approach at primary school. Directorate of Primary School, Jakarta, 2013.

[3] Fogarty, R. Ten Ways to Integrate Curriculum, Educational Leadership Journal, vol. 49, no. 2, pp. 61-65, 1991.

[4] Tawil, M, Liliasari. Complex thinking and its implementation in science learning. Universitas Negeri Makasar, Makasar, 2013.

[5] Schaal B,S,M,B, Girwidz R, Concept Mapping Assessment of Media Assisted Learning interdiciplinary Science Education, Research in Science Education, vol. 40, no. 3, pp. 339-352, 2010.

[6] Yuliati, L, Effectivity of material teaching integrated science to capability of high order thingking in Junior, Journal of Physic Education Indonesia, vol. 9, pp. 53-57, 2013.

[7] Wahyuni, S, Development of science material teaching to increase cpability of critical thinking in Junior, Journal of physic content and learning, vol. 5, no. 2, pp. 47-52, 2015.

[8] Susana, Y, Development of science integrated module based on critical thinking with ventilator theme in Junior, Inquiry Journal, ISSN: 2252-7893, vol. 4, no. 2, pp. 102-115, 2015, http://jurnal. fkip.uns. ac.id/index.php/sains.

[9] Sukarno, Role of BAHAS to SEE in incerasing mastery content and science process skill, Disertation, Universitas Pendidikan Indonesia, 2015.

[10] Frankel, J.R., Wallen, E.N., Hyun, H., How to design and evaluate research in education, Mc. Graw Hill, New York, 2012.

[11] Creswell, J.W. Research Design. Qualitative, Quantitative and mixed approach, Pustaka Pelajar, Yogyakarta, 2014. 